\title{
Community Forest Through Asset Based Community Development:
}

\author{
Community Empowerment
}

\author{
Rika Fitri Ramadani ${ }^{1}$, Toto Suryana ${ }^{2, *}$, Nunu Heryanto ${ }^{1}$ \\ ${ }^{1}$ Community Education, ${ }^{2}$ Islamic Religious Education \\ 1,2 Universitas Pendidikan Indonesia \\ Bandung, Indonesia \\ *totosuryana@upi.edu
}

\begin{abstract}
Sedimentation caused by degradation and deforestation is a major environmental problem around Citarum river, one of the river in Indonesia. Environmental preservation by initiating community forests is the best solution to overcome this problem. Empowerment is not just to stop environmental damage but must pay attention to efforts to conserve the environment in sustainable development in ecological, economic, and socio-cultural aspects. Empowerment is directed at increasing community independence which leads to a willingness to develop awareness, knowledge and skills for welfare. Community forest is a community empowerment program based on economy and environmental conservation implemented by the Bening Sanguling Foundation. The purpose of this research was to analyse the assets and the proses of community empowerment. The research method used is qualitative using a case study approach. Data were collected through observation and interview technique. The informants consisted of two program managers and three program participants. Data obtained then analysed by procedures of data collecting, data reducing, data display, and conclusion. The result of this research indicated that community forests emphasize the importance of ecological conservation without leaving the socio-economic interests of local communities. This program is implemented through three efforts, namely enabling, empowering and protecting. the assets utilized are human, social, physical, financial, and environmental assets. The conclusion obtained from this study was that empowerment process could create an independent community in looking for family livelihood and prosperity.
\end{abstract}

Keywords-sedimentation, degradation, community forest, empowering community

\section{INTRODUCTION}

The people of West Java were shocked by the World Bank's statement in 2018 that the Citarum river one of river in Indonesia was the dirtiest river in the world. The toxins in the Citarum are 1,000 times the safe limit for drinking water in the United States. Even though Citarum water is used by 30 million people in Jakarta, Bekasi, Karawang, Purwakarta and Bandung for irrigation, washing, and even drinking.
This "title" certainly embarrasses us, including President Joko Widodo. Jakarta is home to all national embassies, actors and international business centres. If the tap water comes from the dirtiest river in the world, then what? Apart from that, it is a very important fact that: (1) Citarum is the longest $(269 \mathrm{~km})$ and largest river in West Java which always interacts significantly with various sectors. (2) Citarum has provided donation to various sectors (particularly the downstream sector): (a) supplying water resources for power plants in three large reservoirs that generate electricity for the Java-Bali interconnection; (b) water sources for irrigation of rice fields covering an area of $\pm 300,000$ hectare in the food barns of West Java (even nationally); (c) raw water sources for PDAM 10 districts/cities in West Java and the capital city, Jakarta; (d) Water sources for West Java industrial estates, especially in the Greater Bandung, Kerawang and Bekasi areas; (e) The Citarum watershed interacts with 14 million people, and every year it continues to grow.

The President issued Regulation Number 15/2018 concerning the Acceleration of Pollution Control and Damage to the Citarum Watershed. The goal is to save and preserve the Citarum. The Governor of West Java leads the Citarum Task Force which involves all organizations that intersect with this river. According to Deputy Coordinating Minister for Maritime Affairs Safri Baharudin, Citarum has the criteria for the dirtiest river in the world because, first, there are at least 1,900 industries along the Citarum watershed with liquid waste around 340,000 tons per day. Second, in the upstream area there has been a massive conversion of protected forest land for agriculture. This triggers erosion and sedimentation. There are at least 80,000 hectares of land categorized as critical and very critical which need to be reforested immediately. Third, Citarum is also polluted by people's domestic waste, ranging from household waste to human waste. The amount of household waste is 20,462 tons per day, $71 \%$ of which is not transported to the final disposal site. A total of 35.5 tons per day of human waste and 56 tons per day of animal or livestock manure are also dumped directly into Citarum. 
According to Dr. Anang Sudarna, former Head of the West Java Environment Agency, the cause of "Citarum is seriously ill" is human misconduct, such as: (a) careless conversion of land (use of forests, gardens and non-forest protected areas), (b) disposing of sewage animals (generally dairy cows), (c) agricultural and fishery cultivation is not environmentally friendly, (d) disposal of domestic waste, including toilets in Citarum. (d) disposing of industrial waste without being treated, and (e) the law of the environment is powerless

Tribun Jakarta in 2019 explains that one of the ways to preserve the Citarum river is to overcome erosion that brings sedimentation of mud which will lead to silting in the Citarum watershed (DAS) by reforesting in the form of tree planting trees not only functions for greening but also to absorb water, resist erosion and is useful for preventing flooding.

Bening Saguling Foundation is a community empowerment institution that has vision of becoming an open and transparent community economic institution that is able to increase the dignity and life of community at large while still based on environmental preservation. This Foundation has initiated the formation of community forests where the big agenda is to reduce sedimentation and improve the economic welfare of the people around the river by greening the riverbanks through routine planting of hard trees and fruit trees. The dedication and hard work during 19 years of struggling with environmental preservation has invited appreciation from various parties both from within the country and abroad. He got countless awards. This move has also attracted the attention of foreign media who often come to cover activities at the Bening Saguling Foundation. Indra Darmawan (48) founder of Bening Saguling said, based on the Decree of the Minister of Environment and Forestry of the Republic of Indonesia Number SK.302 / MENLHK / PEG.7 / 7/2020 Regarding the Kalpataru Award 2020 dated July 24, 2020, Bening Saguling Foundation won Kalpataru in the category Environmental Saviour.

Community forest program is a form of empowerment that is managed directly by the community with the aim of increasing family economic income based on environmental aspects. Community forests emphasize the importance of ecological conservation without leaving the socio-economic interests of local communities. How is the process and impact of empowering community through community forest in Bening Saguling Foundation in accordance with the conditions of the community and the environment around the Citarum River? The purpose of this research is to analyse the process and impact community forest through asset to increase community welfare and regional preservation through activities that are has been agreed upon so as to ensure a balance of ecology, economy and social so that the creation of a civil society that is independent, moral, disciplined, creative, wants to advance, is ready to compete and prosperous.

\section{RESEARCH METHODS}

This research was designed using qualitative methods with a case study approach. Qualitative research is a method to explore and understand the meaning of individual or a group of people ascribed to social or humanitarian problems [1]. The case study approach is carried out because of the issues discussed in this study only apply to this institution. Case study is a more suitable approach if the subject matter of a research deals with "how" or "why", if the researcher has few opportunities to control the events that will be investigated, and when the focus of his research lies on contemporary (present) phenomena in a real-life context [2]. Case study is used in this research to provide a comprehensive overview and analysis of facts about community empowerment program through community forest in Bening Saguling Foundation.

The participants of this study were six persons from Bening Saguling Foundation. The participants are ID as the chairman of Bening Saguling Foundation, WN as head of community forest program, DY, MD, and RI as program participant of community forest in Bening Saguling Foundation. ID and WN are used as primary data, while DY, MD, and RI participation are used as secondary data.

Data is collected and extracted through in-depth interviews and observations as a source of triangulation data that can be accounted for its accuracy. The data in this study were collected through several tools, namely interview guides, observation sheets, and documents, taking notes on the results of interviews and observations. The qualitative analysis process in this study has 4 important components, including data collection, data reduction, data display, and conclusions [3].

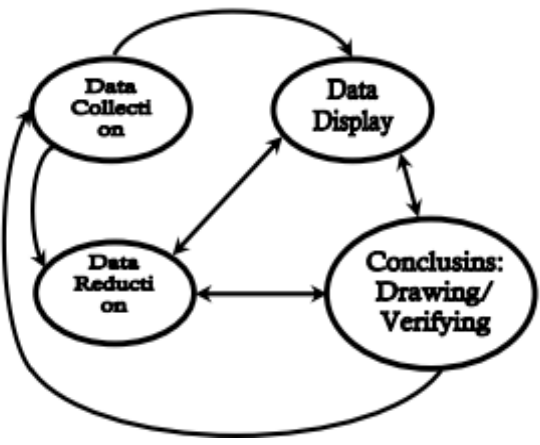

Fig. 1. Interactive data model components.

The data collection phase was carried out related to data empowering community through community forest in Bening Saguling Foundation. Data collection is done before, during, and after the research process is carried out. Data collection is obtained from various sources that are collected sequentially and systematically to make it easier to compile research results.

The reduction phase is the selection process, formulation of attention to simplification or concerning data in the form of detailed (systematic) descriptions (reports), highlighting the important points to be more easily controlled. At this stage the researcher focuses on the collected field notes, namely matters 
relating to empowering community through community forest in Bening Saguling Foundation. The data reduction stage is carried out continuously during the research. Data reduction is a form of analysis that sharpens, classifies, directs, and discards data that is not related empowering community through community forest in Bening Saguling Foundation. Next, a summary, coding, and tracing of themes are made, making a small note that is felt important at the instant. These events and impressions were chosen only relating to empowering community through community forest in Bening Saguling Foundation.

The data presentation stage is an attempt to present data to see the overall picture of the data or certain parts at the research stage. At this stage, data on findings in the field are presented in the form of narrative texts, namely verbal descriptions of empowering community through community forest in Bening Saguling Foundation. After the data is focused and specified, the presentation of data in the form of a report is made. But if the data presented needs to be reduced again, then the reduction can be done again to get more appropriate information. After that the data is simplified and systematically compiled about things that can give an idea of empowering community through community forest in Bening Saguling Foundation.

The conclusion and verification phase is an effort to find meaning for the data collected by looking for patterns, themes, relationships, equations, things that often arise and so on. At this stage a truth test is carried out on each data that appears from data obtained from one subject to another subject. This conclusion is made in a brief and easy to understand statement by examining the main issues related to empowering community through community forest in Bening Saguling Foundation.

\section{RESULTS AND DISCUSSION}

\section{A. Bening Saguling Foundation}

Starting from the concern of environmental damage in Citarum river caused by a pile of plastic waste, water hyacinth weeds and the Citarum river get shallow due to the continuous sedimentation rate entering the Citarum river which results in siltation of the reservoir, and the social conditions of the people living around the reservoir. There are still many who are poor, so an idea was born to build a symbiosis of mutualism between community empowerment around the reservoir with efforts to preserve the environment of Citarum river, so that in 2009 Bening Saguling Foundation was established to accommodate environmental conservation activities as well as community business entities where the members are scavengers and the poor community around the Saguling reservoir.

Bening Saguling Foundation initiated the formation of community forest. This program implements a big agenda, namely mobilizing the community to reduce sedimentation by greening the banks of the Citarum river by regularly planting hard trees. The overall management of this program involves the community with assistance by the foundation. Forest land management is not only intended for production crops, but also for planting crops and smallholder crops. The whole yield of the plants / trees is left to the community as a whole. The public can use it both for consumption and for sale to other parties.

Community empowerment in Bening Saguling foundation refers to environmental preservation. The principle of empowerment program in this institution is "Self-sustaining environmentally sustainable society" which means that every empowerment program implemented in this institution leads to community independence, both economically, socially, politically, and spiritually and this is coupled with environmental preservation. The community must be able to maintain and care for the environment in which they live and make a living.

\section{B. The Process of Empowering Community through Community Forest in Bening Saguling Foundation}

The community forest program, which is one of the community empowerment programs to strengthen the capacity so that the community can participate in accessing resources to improve the quality of life. This program equips people with various kinds of knowledge and skills in conducting land conservation and tree nurseries, stimulating and raising public awareness of the importance of environmental protection, increasing community capacity in business management, increasing community participation in development, and increasing community sensitivity and awareness of environmental conditions so that can jointly create an independent community and a sustainable environment. Community empowerment through community forests is carried out in three ways, namely:

1) Enabling: This effort begins with the process of generating public awareness of the potential for themselves and their environment. This awareness process is carried out through direct socialization, discussion and family dialogue with the local community. The institution invites the public, conducts outreach, discusses and dialogues by going directly to the community. This effort is carried out with the aim that the potential of the community is aware of the potential they have so that they have the determination to develop it in order to improve their standard of living.

The community manages it into productive land to improve the family economy. Most of the plants planted on this community forest land are Bamboo, Aren, Albasia, Tisuk, Ugandan Mahogany, Damar Wood, Sea Katapang, Sewun Buto, Cadar Onduras, Tarum, Manglit, Cinnamon, Pine, Flamboyant, Terep, Noni, and others. The program manager opens access to the community to save trees in community forests which are jointly managed by the village community. Trees planted by the community are used to increase family income.

Communities carry out tree nurseries, planting and management. High community participation in teak forest management will have an impact on two aspects, namely the 
economic aspect where community income will increase, and the ecological aspect where this participation will greatly contribute in maintaining forest sustainability. Enabling efforts are carried out through deliberation beforehand with the community leaders. Managers establish good cooperation with community leaders by taking a family approach, either directly or indirectly to village heads, heads of RT and RW, subdistricts, sub-districts, community leaders, such as religious leaders: ustadz ustadzah / reciting teachers, traditional leaders, educational leaders, youth leaders, entrepreneurs, village community social organizations, and environmental analysts / environmental extension agents. This is done so that the empowerment activities carried out are of higher quality and can be effectively implemented in the community.

2) Empowering: The community is equipped with knowledge, experience, information, skills related to land management so that the results can be used to improve life. The institution seeks to increase community knowledge and skills through training, mentoring and counseling, as well as developing business opportunities. Apart from that, the institution also tries to instill the values of respecting everything in the environment, caring for the environment, and the value of hard work. The addition of knowledge and skills carried out by the cooperative starts from critical land conservation methods such as vegetative methods and mechanical technical methods, plant planting in stripes (strip cropping), reforestation and making of mounds, and so on. Managers continue to facilitate people who need knowledge beyond information related to water hyacinth skills.

The process of implementing community forest empowerment programs in cooperatives is carried out with the existence of a parallel relationship between the manager and the assisted community and the facilitator. Managers position themselves the same as the others and feel and experience what the assisted communities do in their daily lives, this can be seen from the aspect of dressing or appearance that is not conspicuous between all of them. This equal or equal atmosphere makes the assisted community feel comfortable and have high self-confidence so that they want to be embraced and share their learning experiences with all parties. So there is no gap or gap in the implementation of this empowerment program. An equal atmosphere makes people feel considered and respected or taken into account so that they do not feel inferior and do not have a negative self-concept because people who have high self-confidence can see a bright future.

Managers also apply the principle of self-reliance in implementing community forest empowerment programs which are also enforced by the institution. The assisted community who has been provided with learning experiences is given the trust by the institution to be independent in developing their existing abilities. The community is given the trust to develop a plant management business in their respective homes or family land locations so that they do not always depend on other parties. The cooperative believes that the community can and has the ability to develop themselves and their families but they are not completely released because the institution provides sustainable development.

The institution provides opportunities for the target community to participate in these empowerment activities. The community is involved as a whole in the process of decision making, planning, implementing, monitoring, evaluating, and using program results proportionally in the implementation of this activity. The community is involved in deliberation, deliberation, and community discussion as well as the entire series of implementation of this program. Sometimes people take the initiative freely in the development of their activities and businesses.

The implementation of the water hyacinth empowerment program has a direct impact on the improvement of cooperative institutions, which can be seen from the first several aspects, aspects of clarity of vision, mission, and organizational culture. the manager formulates the vision and mission of this institution clearly so that the design of the learning program initiated or designed does not deviate far from the vision and mission formulated. Likewise, with the organizational culture, cooperative institutions have a strong tendency towards comprehensive community empowerment processes, namely consistent development of the community, both in the economic, environmental, social and spiritual fields.

The institution tries to gradually equip the production facilities and equipment used in the community forest program to support the tree production and management processes carried out by the assisted communities. Production facilities that are equipped by this institution are such as sinso machine technology for cleaving wood as well as tools and sets of land management equipment, such as hoes, saws, machetes, and others. In addition, the institution is also trying to gradually improve infrastructure, buildings and internet connection networks available for community development. Infrastructure and buildings developed such as increasing the number and capacity of huts / rooms, halls, bathrooms, kitchens, workshop buildings, web and Wifi Indihome are open to the surrounding community.

This institution is also trying to develop access to capital as capital / operational costs for the implementation of this empowerment program. The institution seeks to develop a community forest management partnership network. Government and private institutions are being embraced gradually in the successful implementation of the program. The manager applies a tree saving system to all assisted communities. This system allows the community to save trees for later harvesting or harvesting.

Improvement of the environment affected by the implementation of the community forest empowerment program, namely the Citarum river environment close to the Saguling reservoir, starting to be clean, healthy and sustainable. The minimization of the sedimentation rate that occurs due to erosion that occurs on the banks of the river results in silting the river which makes the river flow more swift downstream due to forest or land degradation. This program allows the 
community to repair it again by planting various kinds of tree and plant seedlings on the riverbank near the Saguling reservoir (reforestation). Not only satisfied with this activity, the community also manages plants in their own homes or close to their neighbourhood so that they can be used in their daily life.

The values of kinship and mutual cooperation are very strong in the midst of society. The institution tries to strengthen and cooperate with the values that have been built for a long time. The assisted communities are grouped according to their kinship. This program is implemented through deliberations or deliberations and discussions with the community through inperson meetings. Managers openly involve village communities in joint decision making related to program planning, implementation, monitoring and evaluation. All these processes are carried out in a friendly manner, with openness and high solidarity. Decisions made based on collective agreement are not agreed upon by certain parties.

Managers and their ranks develop interpersonal communication patterns that are personal and equal. This is done so that the assisted community feel comfortable and close so that they are open to all parties in the context of selfdevelopment and family development. The institution believes that the best teacher is experience, therefore the experience of the community in the field of land management is brought to the surface during this empowerment process. The interaction between the assisted communities and the facilitators is carried out directly (face to face) so that the close relationship between all of them is well established.

The institution takes into account power, leadership, and influence in this empowerment process. First, cooperatives work with people who have power and influence in the environment. The cooperation established by this institution involves the head of the RT and the head of the RW as leaders who have influence and power over the community. Second, cooperatives focus on leadership that has power and influence in society. This leadership is clearly recorded in the management structure of the cooperative. Third, cooperatives spread leadership that has power and brings influence to society. This effort is carried out by forming the community into small groups led by a chairman. Leadership is not only centred in the management of cooperatives but is spread to all levels of society below. This leadership development is reflected in the appointment of an empowered coordinator and group chairman for each family (developed in the form of joint meetings). Communities are treated as actors in the empowerment process. The leadership that is built is formed from people who have never taken a role at all. Managers form a group coordinator for each empowerment area as well as a group leader consisting of family heads. In this case, this small group is composed of family members / kinship where one group is led by one head of the family who is also the group leader. Managers and facilitators also condition each of these family groups to interact with each other with the aim of selfdevelopment of each group in improving the family economy (group solidarity is something that counts).
This community forest program is implemented through the formation of small groups and a collective process of developing community critical awareness. This small group is formed from the family lines of each of the assisted communities. Managers use an approach that is family friendly and in accordance with the daily life of the local community (informal approach). The implementation of this empowerment program is also supported by supporting resources, namely the development of partnerships established by cooperative institutions with various government and private institutions. The empowerment efforts carried out here are centred on prevailing values and morals. The process never violates religious, social, legal, customary and cultural values or norms, as well as the values of politeness and the environment that are upheld in empowering the community and on the contrary these prevailing values are used as the basis for developing activities in the process of empowering village communities. Cooperative institutions seek to strengthen and cooperate with values that have been built up for a long time in the midst of this society, such as the values of kinship and mutual cooperation.

This institution collaborates with local goals and needs felt by the community. The local goal imposed by the government related to the resolution of the Citarum problem is "Citarum Harum" which initiated a waste management program and environmental preservation. Seeing this opportunity, the cooperative establishes good synergy with existing local objectives. In addition, this institution also introduces a new goal of improving the community's environment, namely "Community Self-Sufficient Environment", which means that the community forest program implemented can contribute to community income. This empowerment process also emphasizes group dynamics in arousing group spirit, focuses more on strengthening individuals in the group, upholding mutual agreement, establishing mutual relations between all components, and using two-way communication strategies in small group settings (allowing people to share experiences) so that they can develop themselves.

The output of the training process for this community forest program was an increase in the ability of training participants, which was seen from the ability of participants to carry out land management in planting various types of plants such as timber trees, fruit, family medicinal plants, and others, increased awareness and understanding of the community in maintaining and preserving the environment (caring for the environment), as well as the growth of positive attitudes towards themselves and their families, the community is more appreciative of themselves, has self-confidence, looks at the future optimistically, is serious in trying and appreciates everything around it does not like it in vainsia / redundant. In addition, there is an increase in the institutional or physical capital of cooperatives such as facilities (appropriate technology), additional huts / rooms and others. This production facility is used collectively and is open to all assisted communities in the process of land management so that it is productive. 
The outcome obtained in the skills program is that there are assisted communities who manage community forest land through a tree saving system where the results can be enjoyed by the community for a certain period of time and carry out land management activities in their respective homes. This land is used for cultivation by the community of various types of plants, such as spices / rhizomes and family medicinal plants which are used by the community in their daily life.

3) Protecting: Institutions seek to protect empowered communities. The cooperative institution accommodates the community in managing community forest land where the community can save trees to be harvested at a certain time. In addition, the community is given the opportunity to develop a business in the hope that the community will be able to be independent and able to make the right decisions through the development of a credit system, namely "waste paid savings and loans".

\section{Analysis the Assets of Community Forest: Empowering Community in Bening Saguling Foundation}

Bening Saguling Foundation has implemented a village community empowerment process in the form of a community forest program in a sustainable manner. Assets are not always synonymous with money or material. Many things that are owned by the community but are not realized are part of assets. The asset mapping process is carried out so that the community is aware of the assets they own and the benefits they will get when they synergize these assets together. The objectives of this stage are:

- To increasing awareness of possible actions

- Awareness of how to work with others and coordinating input

- Decisions about what to do based on the available resources

- Less dependence on outsiders to make progress

- Higher sense of partnership in contributions from outside parties including government agencies

The assets that are utilized in this empowerment process are:

1) Human asset/capital: The power of society can be a starting point for the development of a country with the human element as the basic capital of development. Most of the livelihoods of the forest village community are farmers, farming activities and gardening. This program utilizes the basic knowledge and skills of the community in plant and forest management that they have learned from generation to generation from their parents so that the next generation will automatically be able to do it by themselves. No matter how small an asset is, it will be very useful if it is realized, utilized and developed optimally.
This village also has several experts from the surrounding community with relatively high levels of education, namely graduates with degrees in agriculture, forestry and mining. They are experts in their respective fields and are actively involved in contributing to the implementation of this program. These capitals are used by program managers to improve community welfare. So it can be concluded that in a community every citizen has the potential and skills such as physical, emotional and intellectual skills to contribute to the progress of society. In the process of community empowerment, the combination of individual abilities will bring maximum change.

2) Social capital: The biggest capital in a community empowerment program is the existence of social capital that connects one community group to another. The social capital that is utilized is the values and norms that apply in society (rules that bind and regulate the patterns of community behavior in it), public awareness of the same conditions, community trust, and the network that is established. The community actively participates in village development. The form of participation that is carried out is usually in the form of mutual cooperation to repair public roads or forests, clean up the environment around settlements and forests, work on agricultural products, organize various community events, such as weddings, payroll, visit people who are sick, die, help build houses of worship, sanitation channels and clean water and others. This activity further encourages community participation and involvement to be able to protect and preserve the environment and increase mutual welfare.

Another social capital that is used is institutional partnerships with other institutions. Partnership is one of the main assets needed to maximize the position and role of the community in the empowerment process. This is done with the intention that the community must become the main motor and mover in the process (community driven development) because in the community a sense of belonging has been formed so that there will be a maximum empowerment process.

There are quite a lot of partnerships involved in this empowerment program, both government agencies and private institutions from within and outside the country, such as Baznas, West Bandung District Health Office, Bappeda Kab. West Bandung, BPMPD Kab. West Bandung, PKBM as Kab. West Bandung, Department of Industry, Trade, Cooperatives and Small and Medium Enterprises, West Bandung Regency, Rumah Amal Salman ITB, PT. Waste for Change Alam Indonesia, District Government. Anambas Kep. Riau, NGO Ecolink, Department of Fine Arts ITB, Telkom University, Unicom, Bandung City Women's School, Kab. West Bandung, STKIP Pasundan, Dekranasda West Java, University of Education Indonesia Bandung, DPMPD Kab. Karawang, Greeneration Indonesia, Nice Japan, Concordia Francis, Great Indonesia, and others. In addition, this institution also embraces social community organizations / associations formed in villages such as youth organizations (Karang Taruna, etc.), PKK, Tahlilan community, soccer clubs, GAPOKTAN 
(Farmer Group Association), HIPPA (Water Taking Farmers Association)), and others. All of these organizations are invited to collaborate in organizing this community forest program so that all community potentials can be maximally developed and empowerment goals can be achieved together.

3) Physical asset: Assets are not always synonymous with money. Physical assets are one of the basic assets contained in every society. The main groups of physical capital utilized by this institution are infrastructure, production facilities and buildings. The infrastructure in question is in the form of roads, bridges, railroad tracks, waste disposal facilities, clean water supply facilities, and others. Production facilities can be in the form of tools and machines for farming and gardening, machinery for processing forest products, means of transportation and others. The buildings in question are in the form of forest farmer cooperatives, commercial buildings, secretariat of foundations, and others.

4) Financial assets: Another capital that needs to be taken into account and determine the welfare of forest village communities is financial capital. This institution maximizes the function of cooperatives in supplying finance for forest village communities in need. The cooperative applies a savings and loan system to the community, capital in the form of money, procurement of seeds and plant fertilizers. People can access capital. The institution also uses the leaky bucket approach to make it easier for the community to explore, identify and analyze various forms of activity or the turnover and turnover of the local economy owned by the community. The results can be used to increase strength collectively and build it together. This approach allows the community to visualize what economic assets they have by using the flow of cash, goods and services that enter from the top side and exit from the bottom side of the economic container as a potential that is owned by the community.

5) Environmental assets: Another very important asset in the community forest program is the existence of environmental capital that can be accessed and utilized by the community. Environmental capital can be in the form of untreated potential such as agricultural land and plantations, clean water, rivers, trees, etc. which have economic value and have value in nature conservation efforts, such as prevention of degradation, erosion, sedimentation of the environment. Prior to the implementation of this community forest program, environmental damage occurred very much where river water was dirty, forests were damaged, and land was critical.

\section{CONCLUSIONS}

This research provides some reinforcement that community empowerment remains the most relevant process in community education. The empowerment process will be stronger if it is supported by bright program which will later make the community steady in the empowerment process. The community forest program is a form of empowerment that is managed directly by the community with the aim of increasing family economic income while still paying attention to environmental aspects. Community forests emphasize the importance of ecological conservation without leaving the socio-economic interests of local communities. This program is implemented through three efforts, namely enabling, empowering and protecting. The impact of this program can be seen from both the social, economic and environmental aspects of the community. Changing social economic structure and function and also environmental was the impact of this program in empowering process. The presence of this program in the process of community empowerment can provide an illustration that managers can maximize the potential or resources available in the community. So that all the potential and opportunities contained in society can be built and developed properly and optimally.

\section{REFERENCES}

[1] J.W. Creswell, Penelitian Kualitatif \& Desain Riset: Memilih diantara Lima Pendekatan. Yogyakarta: Pustaka Pelajar, 2017.

[2] R.K. Yin, Case study methods, 2012.

[3] M.B. Miles, M.A. Huberman and J. Saldana, "Drawing and verifying conclusions," Qualitative data analysis: A methods sourcebook, pp. 275322, 2014. 